\title{
Survey Protocol for the Richardson's Ground Squirrel
}

WILDLIFE CONSERVATION AND BIODIVERSITY SECTION

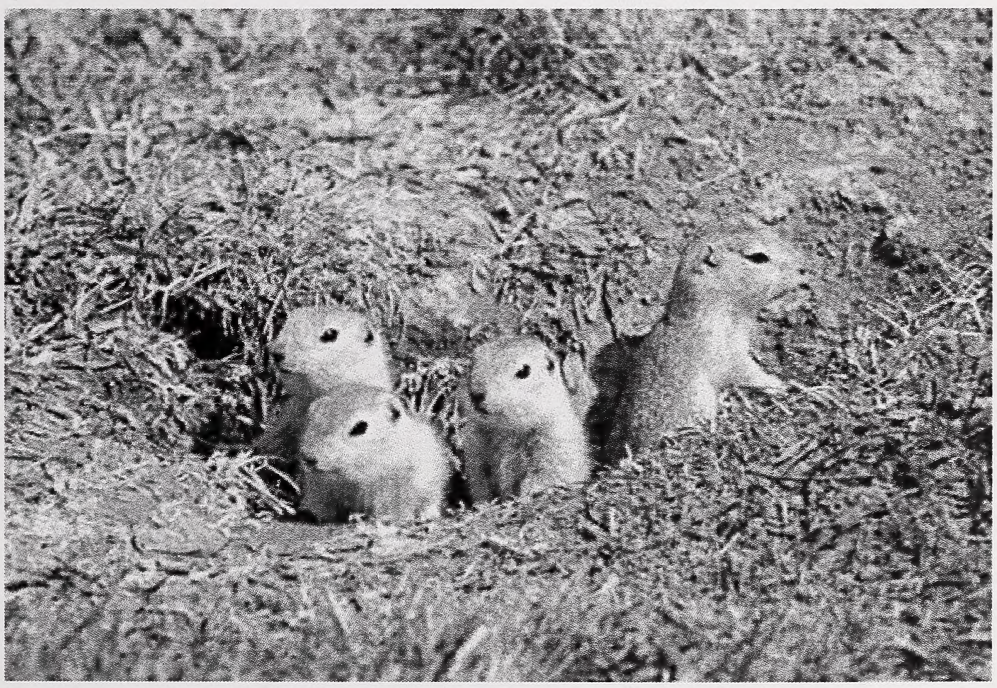


Digitized by the Internet Archive in 2016 


\title{
Survey Protocol for the Richardson's Ground Squirrel
}

\author{
Brad A. Downey
}

March 2003

Alberta Species at Risk Report No. 69

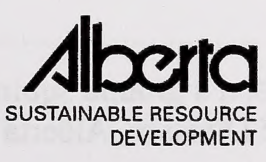

Fish \& Wildlife

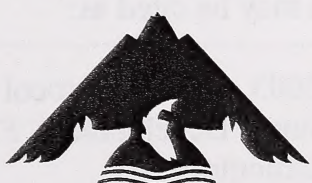

Alberta Conservation Association 
Publication No. I/108

ISBN: 0-7785-2825-1 (Printed Edition)

ISBN: 0-7785-2826-X (On-line Edition)

ISSN: 1496-7219 (Printed Edition)

ISSN: 1496-7146 (On-line Edition)

Cover Photograph: Gail Michener

For copies of this report, contact:

Information Centre- Publications

Alberta Environment/ Alberta Sustainable Resource Development

Main Floor, Great West Life Building

9920- 108 Street

Edmonton, Alberta, Canada T5K 2M4

Telephone: (780) 422-2079

OR

Information Service

Alberta Environment/ Alberta Sustainable Resource Development \#100, 3115- 12 Street NE

Calgary, Alberta, Canada T2E 7J2

Telephone: (403) 297- 3362

OR

Visit our web site at:

http://www3.gov.ab.ca/srd/fw/riskspecies/

This publication may be cited as:

Downey, B. A. 2003. Survey protocol for the Richardson's ground squirrel. Alberta Sustainable Resource Development, Fish and Wildlife Division, Alberta Species at Risk Report No.69. Edmonton, AB. 
LIST OF FIGURES ii

LIST OF TABLES ii

ACKNOWLEDGEMENTS. iii

EXECUTIVE SUMMARY iv

1.0 INTRODUCTION. 1

2.0 BIOLOGY AND ECOLOGY OF RICHARDSON'S GROUND SQUIRRELS..........2

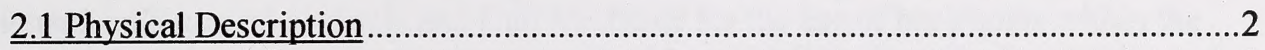

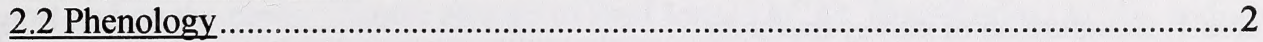

2.3 Habitat Requirements ...........................................................................

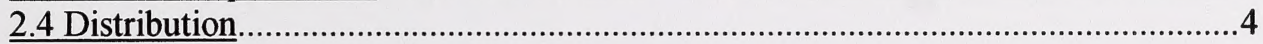

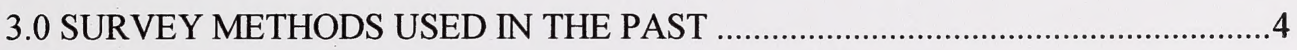

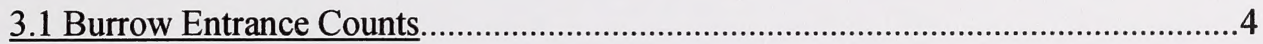

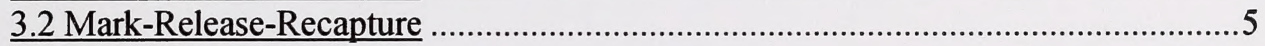

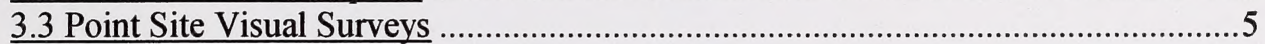

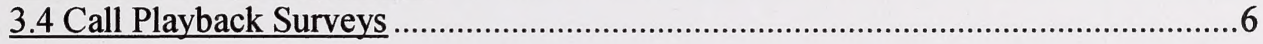

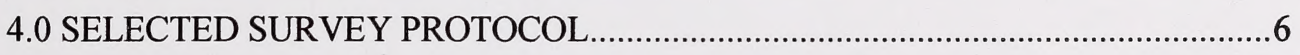

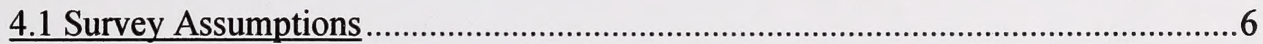

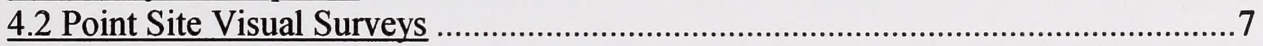

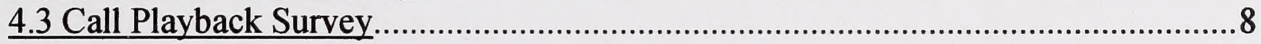

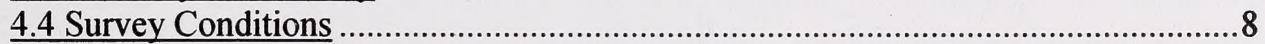

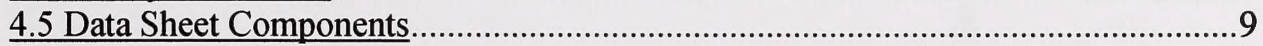

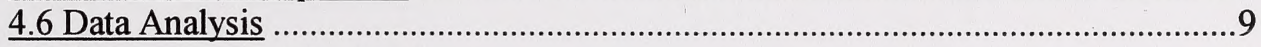

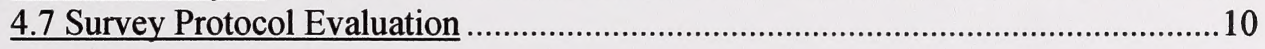

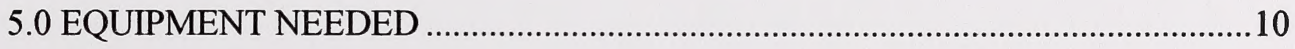

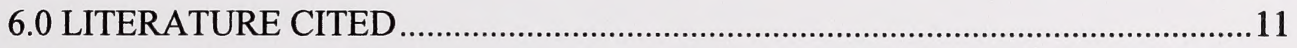

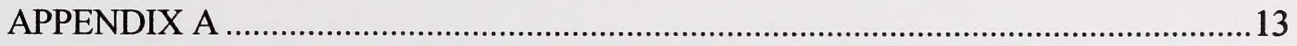

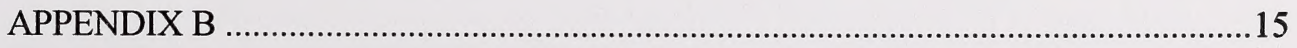

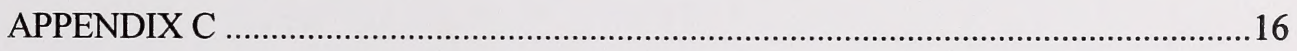

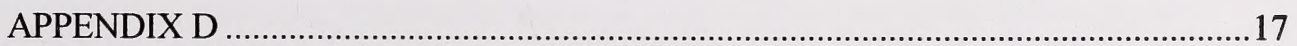




\section{LIST OF FIGURES}

Figure 1. Juvenile Richardson's ground squirrel 2

Figure 2. Average times of emergence from hibernation (adults), emergence from the natal burrow (juveniles), and immergence into hibernation for Richardson's ground

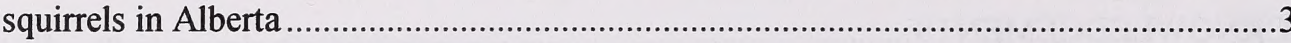

Figure 3. Distribution of Richardson's ground squirrels in Alberta ..............................4

Figure 4. Ferruginous hawk blocks with Richardson's ground squirrel transect................7

\section{LIST OF TABLES}

Table 1. Comparison of survey methods .5 


\section{ACKNOWLEDGEMENTS}

Funding for the project was provided by the Alberta Fish and Wildlife Division (AFWD) Species at Risk Program. Alberta Conservation Association (ACA) is thanked for assisting with project administration. Steve Brechtel (AFWD), Richard Quinlan (AFWD), and Paul Jones (ACA) are thanked for arranging funds and administration of this project. Thanks also go out to Richard Quinlan for his supervisory role, helpful suggestions, and editorial comments.

I would like to thank the following people for their time, suggestions, comments, and reviews. Gail Michener (Department of Biological Science, University of Lethbridge), Jan Murie (Department of Biological Science, University of Alberta), and Ursula Banasch (Canadian Wildlife Service). I thank James Hare (Department of Zoology, University of Manitoba) for providing me with the recordings of alarm calls of Richardson's ground squirrels and Gail Michener for the use of her photos within the report and on the cover. Thanks also go to Paul Jones (ACA), Brad Taylor (ACA), and Corey Skiftun (ACA) for editing and providing comments. 


\section{EXECUTIVE SUMMARY}

Richardson's ground squirrels (Spermophilus richardsonii), colloquially known as "prairie gophers", are found throughout the prairie provinces and play a vital role as a prey species for several predators. In the case of ferruginous hawks, Richardson's ground squirrels make up $89 \%$ of the prey biomass (Schmutz and Hungle 1989), so management for this and other raptor species should include studies on their main prey. Behavioural and physiological ecology of Richardson's ground squirrels is fairly well known (Michener 1998, Michener 2002a), but information on population trends in the prairies is less well documented (Schmutz and Hungle 1989, Kirk and Banasch 1996). Population trends have been investigated for Richardson's ground squirrels, other species of ground squirrels, and prairie dogs to determine how prey populations affect their main predator (Schmutz and Hungle 1989, Menkens et al. 1990, Van Horne et al. 1997, Powell et al. 1994).

Past surveys on ground squirrels included burrow entrance counts, mark-releaserecapture, and above ground visual surveys. Above ground visual surveys during playback of alarm vocalisations has been selected as the preferred survey method for Richardson's ground squirrels because it is time efficient and cost effective and should yield the required information. Thirty existing ferruginous hawk blocks were selected to have $12.8 \mathrm{~km}$ ( 8 mile) Richardson's ground squirrel transects placed within them. The surveys will be conducted along these transects during the first three weeks of April when adults are above ground and juveniles have not yet emerged. Surveys will be conducted during specific times of the day and under specified weather conditions when ground squirrels are most active. A second survey may be conducted in June to determine whether population trends in April and June are similar. Analyses of the data will look at whether there are any differences in the number of ground squirrels seen using call playback versus no call playback. Yearly trends using route regression analysis will be calculated for the entire grassland region, each of the five survey areas (Hanna, Brooks, Lethbridge, Medicine Hat, and the Foothills Fescue Region), and the 30 individual hawk blocks. 


\subsection{INTRODUCTION}

Richardson's ground squirrels (Spermophilus richardsonii) are distributed throughout the grasslands and are a key component to the prairie ecosystem. Smith (1993) and Michener $(1996,2002 a)$ identify Richardson's ground squirrels as a vital prey source for ferruginous hawk (Buteo regalis), Swainson's hawk (Buteo swainsoni), prairie falcon (Falco mexicanus), prairie rattlesnake (Crotalus viridis), American badger (Taxidea taxus), and long-tailed weasel (Mustela frenata). Their burrows also provide refuge and shelter for burrowing owls (Athene cunicularia), bumblebees, several species of snakes, and small mammals (Michener and Schmutz 2002). Several researchers have identified the importance of surveying for prey species, such as ground squirrels and prairie dogs, to identify their influences on the predator species that are closely linked to them (Schmutz and Hungle 1989, Menkens et al. 1990, Powell et al. 1994, Kirk and Banasch 1996, Van Horne et al. 1997). Because Richardson's ground squirrels play an important role in the overall biodiversity of the grassland ecosystem a consistent and practical system of monitoring ground squirrel populations is required.

Survey methods used in the past for ground squirrels include burrow entrance counts, mark-release-recapture, and above ground visual counts, but no standardised method has been developed for Richardson's ground squirrels in the grassland region of Alberta. Such a survey needs to be cost effective, time efficient, and be linked to other surveys as part of a grassland-monitoring program. Because Richardson's ground squirrels are widely distributed at different population densities in a wide variety of habitats across the prairies, an estimate on their entire population would be impractical. A more practical goal is to track annual fluctuations in the prairie-wide population by monitoring selected areas. Therefore objectives were identified for a survey which could be conducted yearly at modest investment of cost and time.

- To review the biology and ecology of Richardson's ground squirrels

- To review and compare potential survey methods for application to Richardson's ground squirrels

- To develop a survey methodology to determine yearly trends in population density of Richardson's ground squirrels in Alberta.

- To develop a survey method that can compare trends in Richardson's ground squirrel populations with trends in the ferruginous hawk populations.

Surveys conducted in the past on Richardson's ground squirrels were usually tied into surveys for other species, particularly ferruginous hawk (Schmutz 1989), prairie falcon (Usher et al. 1993), or burrowing owls (Russell 2002, Scobie 2002). Continued multispecies surveys are an effective means of allocating time to surveys. This protocol highlights three survey methods: burrow entrance counts, mark-release-recapture, and point count visual surveys using call playback. It also identifies the reasons why one of 
these methods was selected over others. The time allocation, manpower required, cost, and precision are estimated for each method and rated as high, medium, or low.

\subsection{BIOLOGY AND ECOLOGY OF RICHARDSON'S GROUND SQUIRRELS}

\subsection{Physical Description}

The Richardson's ground squirrel is a medium-sized rodent that weighs $250-550 \mathrm{~g}$, depending on sex and time of year (Figure 1). Richardson's ground squirrels are identified by their small furry ears, furry tail, large eyes placed high on the head, and sandy brown or buffy yellow colour with darker hairs on the back giving a mottled appearance (Smith 1993).

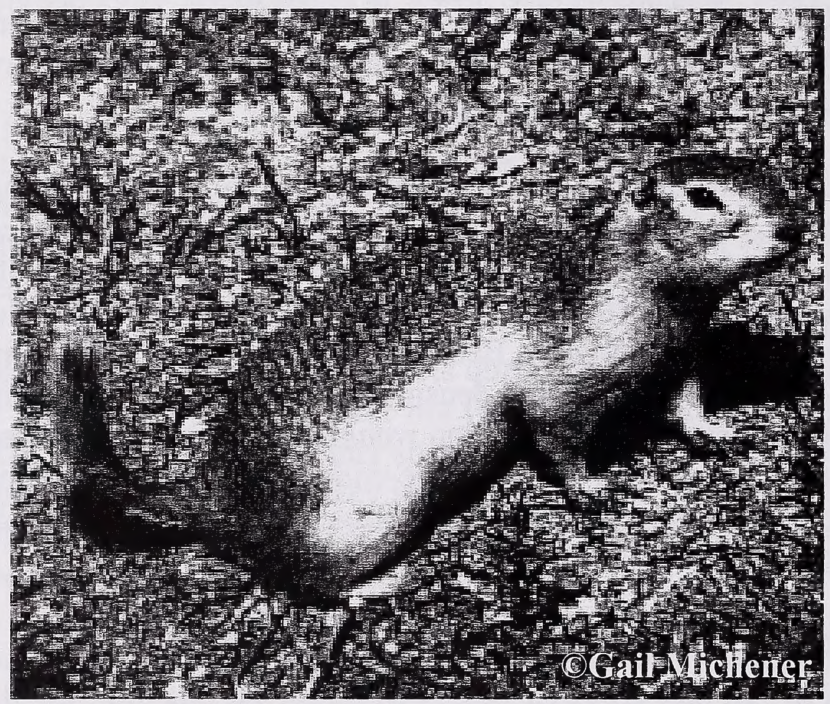

Figure 1. Juvenile Richardson's ground squirrel

\subsection{Phenology}

Male and female ground squirrels are active at slightly different times of the year. Around Lethbridge in southern Alberta, adult males usually emerge from hibernation in late February to early March, and adult females emerge about two weeks later. Adult males then re-enter hibernation (immerge) around mid-June and adult females immerge in late June- early July (Michener 2002a). Juveniles usually first appear above ground in early to mid-May and remain active until early to mid-August for juvenile females and mid-September to October for juvenile males (Michener 2002a, Figure 2). The active season begins 2-3 weeks later in more northerly locations in Alberta. Furthermore, at any location timing of the active season can vary 2-3 weeks between years depending of the severity of the winter (Michener and Schmutz 2002). 


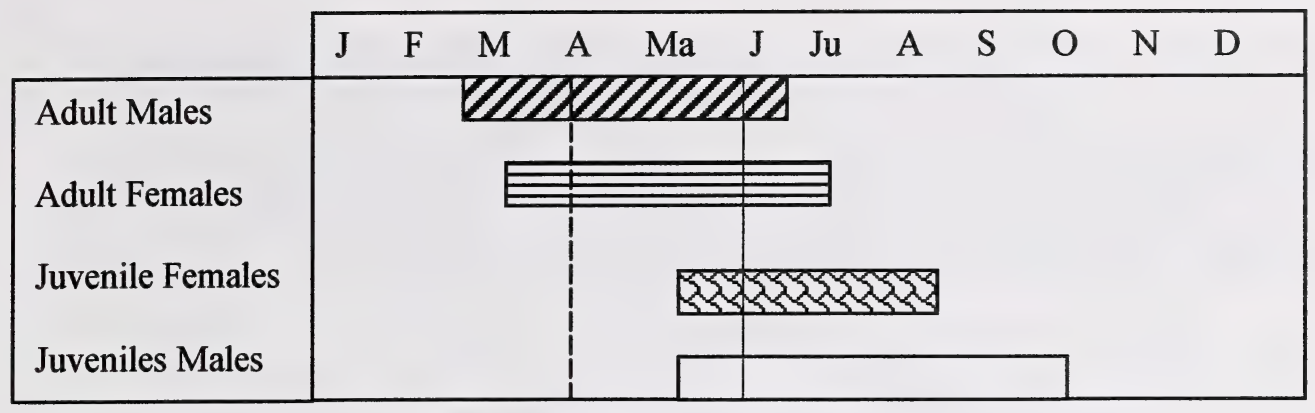

April -survey only adults

June- survey entire population (Presence of adult ground squirrels and attrition of juveniles may vary between years)

Figure 2. Average times of emergence from hibernation (adults), emergence from the natal burrow (juveniles), and immergence into hibernation for Richardson's ground squirrels in Alberta (after Michener 2002a). The dashed line indicates the optimal time to conduct surveys to count the number of adults. The dotted line indicates a second time at which surveys could be conducted.

Richardson's ground squirrels spend about $85 \%$ of their life below ground sleeping and hibernating and are active above ground for only $15 \%$ of their life (Michener 2002b, Michener and Schmutz 2002). They become sexually mature at one year of age. Females are only capable of having one litter per year; even if they lose at litter during pregnancy or lactation, females cannot produce another litter until they hibernate again (Michener 2002a). Mating occurs shortly after females emerge from hibernation. Because females tend to emerge and mate synchronously, all litters are born within a 1 to 3 week period, so all the young ground squirrels appear above ground at roughly the same time. This results in a dramatic increase in the number of animals above ground within a matter of days. However, few young survive to adulthood (10-20\% of the males and $40-50 \%$ of the females) due to predation and other natural causes of mortality (Michener and Schmutz 2002).

\section{$\underline{2.3 \text { Habitat Requirements }}$}

Richardson's ground squirrels are opportunistic and occur not only in their natural prairie habitat but also in native pastures, tame pastures, cultivated fields, hay land, parkland, parks, farmyards, and ditches. They are found in the highest numbers in flat heavily grazed areas and in smaller numbers in taller vegetation (Michener and Schmutz 2002). Ground squirrels can persist on islands of grassland or along ditches surrounded by cultivation (Michener 2002a). A key limiting factor to their habitat requirements may be the type of soil in which they construct their burrows. They do not inhabit sandy or clay soils in which tunnels are prone to collapse (Reynolds et al. 1999). In the locations where they are in sandy soil, Reynolds et al. (1999) found them to be along roadways where the compaction of the area during road construction caused the soil to be stable enough for the excavation of burrows. Ground squirrels are sometimes found in sandy well-vegetated soils. 
An adult female ground squirrel maintains a home range of up to $240 \mathrm{~m}^{2}$ in the summer. Home ranges of females often overlap with those of their close female relatives such as sisters or daughters (Michener 2002a). Home range for males vary throughout the year. During the breeding season the males home ranges can overlap the areas used by as many as 10 females, however after the breeding season males are restricted to small areas by the aggression of pregnant and lactating females (Michener 2002a).

\subsection{Distribution}

Richardson's ground squirrels are found throughout the prairie provinces in Canada and in North Dakota, South Dakota, Montana, and western Minnesota in the United States (Michener 2002a). In Alberta their range extends from the Saskatchewan border west to the foothills where they give way to Columbian Ground Squirrels (Spermophilus columbianus) and from the United States border to north of Edmonton (Figure 3).

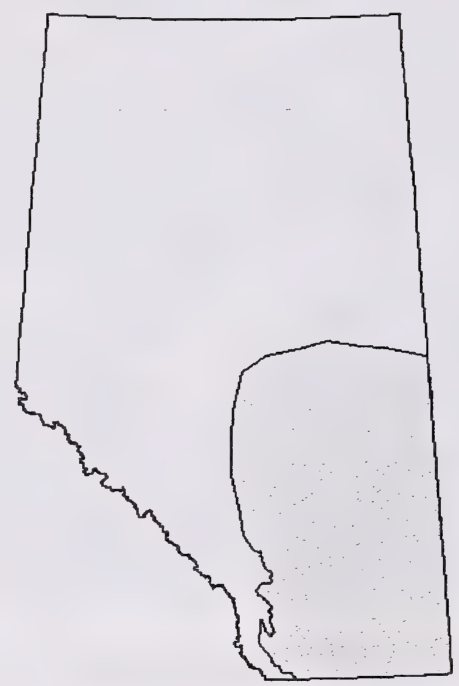

Figure 3. Distribution of Richardson's grounds squirrels in Alberta (after Smith 1993)

\subsection{SURVEY METHODS USED IN THE PAST}

\section{$\underline{3.1 \text { Burrow Entrance Counts }}$}

Surveys such as counts of burrow entrances have been used to determine population density trends for semi-fossorial mammals. Van Horne et al. (1997) conducted burrow entrance counts in western Idaho on Townsend's ground squirrels (Spermophilus townsendii) to determine spatial and temporal population trends. Burrow entrance counts were ineffective at detecting small or moderate yearly fluctuations in population densities. Errors in population estimates arise because burrows persist over time even when not in use, several ground squirrels may use one burrow system, and other species 
may occupy burrows not in use by ground squirrels. Furthermore discrepancies in counts occur between observers (Powell et al. 1994, Van Horne et al. 1997).

Van Horne et al. (1997) found that number of burrow entrances and the density of ground squirrels were not significantly related. They recommended that burrow entrance counts not be used for determining a population trend for Townsend's ground squirrels in shrub steppe habitat and should be verified prior to being conducted in other habitats. Because burrow entrance counts are imprecise at determining yearly fluctuations, have high observer bias (counting inactive burrows as active), require access to private land, and require substantial time and manpower this survey was ruled out (Table 1).

\subsection{Mark-Release-Recapture}

Mark-release-recapture is the usual means of acquiring absolute density estimations for small mammals. Although mark-release-recapture is useful in determining yearly population trends of ground squirrels, the technique is very costly and labour intensive (Van Horne et al. 1997). Personnel would have to be consistently monitoring the traps and handling the animals for marking. Access to private land would also be required. Consequently this survey method is not feasible for yearly monitoring of Richardson's ground squirrels (Table 1).

\section{$\underline{3.3 \text { Point Site Visual Surveys }}$}

Above ground surveys of ground squirrels and prairie dogs have been conducted by several individuals and groups (Lishak 1977, Menkens et al. 1990, Powell et al. 1994, Hare and Atkins 2001). Menkens et al. (1990) suggests that visual counts of white-tailed prairie dogs (Cynomys leucurus) are capable of providing indices of population densities. Point site visual surveys are a quick and simple means of sampling large areas in short periods of time. They are low cost, do not require traps, and are repeatable yearly. Less time is required compared to burrow entrance counts, landowner permission is rarely required, and populations can be observed from afar. Limitations include the survey being restricted to certain times of the day and year when ground squirrels are active and the effect of topography or vegetation on visibility. Time, manpower, and cost are relatively low compared to the other two methods (Table 1).

Table 1. Comparison of survey methods

\begin{tabular}{|c|c|c|c|c|}
\hline Survey Method & Time Allocation & Manpower & Cost & Precision \\
\hline Burrow Entrance Counts & High & High & Low & Low \\
\hline Mark and Recapture & High & High & High & High \\
\hline $\begin{array}{c}\text { Point Site Visual Surveys } \\
\text { Using Call Playback }\end{array}$ & Medium & Low & Low & Medium \\
\hline
\end{tabular}

Above ground visual surveys can be imprecise when surveys are conducted during inappropriate times such as periods of low activity above ground or when there is a 
dramatic change in the population size. Changes in population size can be due to emergence of juveniles from natal burrows, dispersal of juveniles, or staggered times of immergence into hibernation among age and sex classes (Menkens et al. 1990). The following protocol targets the small window of opportunity when activity levels of the ground squirrel population are high and when only adult ground squirrels are above ground. Yearly differences in the timing of mating and the emergence of young would be a concern with later surveys. Emergence of young may vary 2-3 weeks between years and geographic location (Michener and Schmutz 2002). Surveys of adults conducted during the first three weeks in April will alleviate any biases arising from whether or not juveniles are active above ground and simplify the task by just counting adults. Because females can only have one litter a year and because adult females outnumber males by at least 3:1, counts of adults in April should most accurately reflect the size of the reproductive population ( $\mathrm{G}$. Michener pers. comm.).

\section{$\underline{3.4 \text { Call Playback Surveys }}$}

Animal calls have been used for centuries as a means to attract or bring about a response from selected species (Lishak 1977). Most calls were and still are used for hunting purposes however calls are now incorporated into regular wildlife surveys (Lishak 1977). The use of high-pitched whistles or natural alarm calls helps to increase observability of ground squirrels (Leung 1991, Lishak 1977, Hare and Atkins 2002). Alarm calls have allowed researchers to count $63 \%-100 \%$ of the thirteen-lined ground squirrels (Spermophilus tridecemlineatus) actually residing in a population (Lishak 1982). Surveys using call playback for thirteen-lined ground squirrels proved very effective; he counted $44-47 \%$ more ground squirrels during call playback versus no call playback (Lishak 1977)

Hare and Atkins (2001) studied the response of Richardson's ground squirrels to alarm calls in Manitoba. They noted that the ground squirrels responded to the calls with increased vigilance either by standing upright to scan the area or remaining on all fours with their head elevated. This was similar to Lishak's results in which thirteen-lined ground squirrels either ran to their burrow and erected themselves to scan the horizon, erected themselves where they were, or responded loudly to the call playback.

The viability of such a method for surveying Richardson's ground squirrels will be evaluated through these surveys.

\subsection{SELECTED SURVEY PROTOCOL}

\subsection{Survey Assumptions}

It is important that the following survey assumptions are met so that any biases will be consistent. This will allow accurate calculation of trends and comparisons between areas (Ministry of Environment, Lands and Parks Resource Inventory Branch 1998).

- Surveys will be far enough apart so as not to influence each other. 
- Survey protocol will be followed consistently.

- Sampling will not occur during periods of drastic changes in the population size (i.e. when juveniles are emerging or when adults are entering hibernation). By sampling at the start of April only the adults will be above ground.

- All ground squirrels in the $200 \mathrm{~m}$ radius have an equal chance of being seen.

- Ground squirrel movements during the count are minimal so that double counting is minimized.

- Surveys will be conducted yearly during the first three weeks of April to develop consistent yearly trend data for the adult population.

\section{$\underline{4.2}$ Point Site Visual Surveys}

This survey method was designed so it could be conducted in conjunction with ferruginous hawk block surveys. Schmutz and Hungle (1989) found strong correlation between ferruginous hawks and the number of ground squirrels. Surveying for both species may help us to understand the amount of which ferruginous hawk populations fluctuate due to changes in the ground squirrel population.

Point site surveys involve an observer driving and stopping every $800 \mathrm{~m}$ along a $12.8 \mathrm{~km}$ ( 8 mile) predetermined transect. One $12.8 \mathrm{~km}$ transect will be conducted yearly in 28 of the existing ferruginous hawk blocks, five to eight blocks in each of the four Fish and Wildlife areas (Hanna, Brooks, Lethbridge, and Medicine Hat) and an additional two ferruginous hawk blocks in the foothills fescue sub-region (Figure 4). Twenty-eight of the total 30 blocks were also selected as candidates for yearly ferruginous hawk monitoring (Taylor 2003). The ferruginous hawk blocks of $6.4 \mathrm{~km}$ by $6.4 \mathrm{~km}$ ( 4 miles by 4 miles) are scattered throughout the grassland region of Alberta.

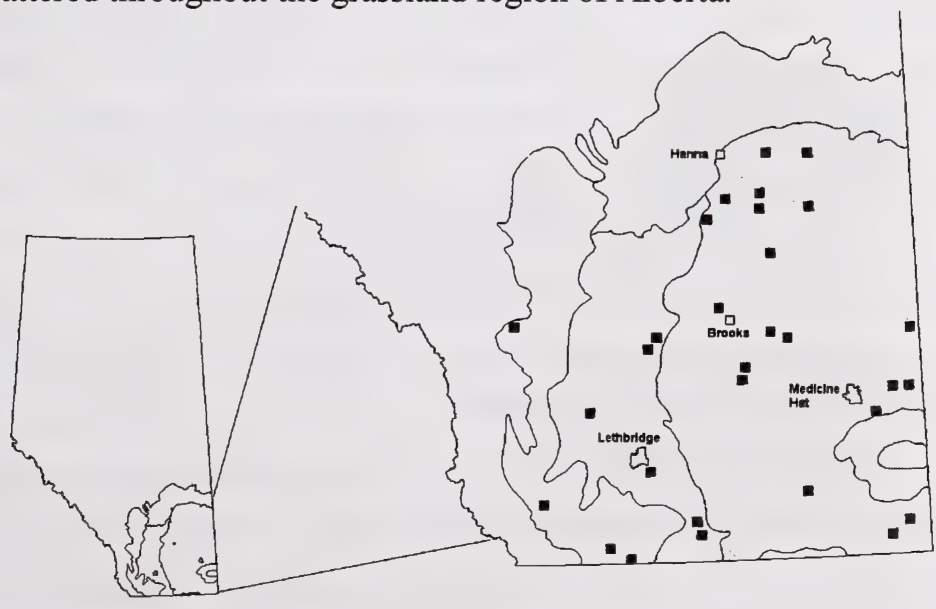

Figure 4. Ferruginous hawk blocks with Richardson's ground squirrel transect. 
The observer will use binoculars and start the survey at a recognisable point then rotate around 360 degrees (four $90^{\circ}$ quadrants) counting each ground squirrel within $200 \mathrm{~m}$ during a 2 minute period. In cases where quadrants cannot be surveyed $200 \mathrm{~m}$ due to obstructions resulting from topography the observers will continue along the transect (up to $400 \mathrm{~m}$ from the original site) until they can see $200 \mathrm{~m}$ in each quadrant. Any changes in the locations of the stops will be noted on the data sheet. Regular intervals of stops every $800 \mathrm{~m}$ will then continued from where the original stop was located. The number of Richardson's ground squirrels seen in each quadrant (NE, NW, SE, and $\mathrm{SW}$ ) will be recorded on the data sheet (Appendix A). The dominant habitat for each quadrant and the habitat in which ground squirrels are seen will be recorded. Any other objects or disturbances seen within the $200 \mathrm{~m}$ survey radius will also be recorded under the column "Disturbances".

\section{$\underline{4.3 \text { Call Playback Survey }}$}

On completion of the first count the observer will then play a recording of the alarm call of an adult Richardson ground squirrel for 30 seconds while facing each quadrant and counting the number of ground squirrels observed. Both counts will be recorded to determine whether playback of alarm calls assists in increasing observability.

The observer will record species of interest (Appendix B) encountered at the stop (e.g. loggerhead shrike Lanius ludovicianus and upland sandpiper Bartramia longicauda) and species that may affect a ground squirrel colony (e.g. American badger Taxidea taxus and coyote Canis latrans). At each site, the observer will also record whether a colony (group of burrows) or an individual burrow exists in each of the quadrants surveyed. The detailed survey method is provided in Appendix C.

\subsection{Survey Conditions}

Surveys will be conducted during the first three weeks of April to ensure that all adult ground squirrels have emerged from hibernation and are above ground. This will allow the maximum adult density to be assessed each year. Surveys for relative abundance to be used for trend data should be conducted when the largest counts are possible as with the emergence of juveniles (Ministry of Environment, Lands and Parks Resource Inventory Branch 1998). However emergence of young may vary 2-3 weeks between years depending on the severity of the winter and geographic location (Michener and Schmutz 2002). April surveys of adults were chosen to alleviate the biases that could result from these fluctuations. Surveys, if time allows, may be repeated during the ferruginous hawk block surveys to see whether trends from April counts of adults reflect the relative abundance in June when juveniles have emerged.

Surveys will be conducted when ground squirrels are actively feeding. Morning surveys will start 75 minutes after sunrise and end by 1200 hours. Afternoon surveys will be conducted from 1600 hours until 75 minutes prior to sunset. Because of reduced levels of activity, surveys will not occur during extremely high temperatures $\left(30^{\circ} \mathrm{C}\right)$ or inclement weather such as snow or rain (NatureServe Explorer 2001, G. Michener pers. comm.). Wind, which seems to be a limiting factor in all surveys where call playbacks are used, 
may not be as great a factor for ground squirrel surveys. This is based upon the assumption that when the alarm call is played squirrels hearing the call will then emit their alarm call to warn others that may not be able hear the primary one. However, surveys should not be conducted in winds over four on the Beaufort Scale (Appendix D).

\subsection{Data Sheet Components}

- Wind speed will be based on the Beaufort Scale and observers will circle the code that corresponds with the wind speed. Descriptions are also given for each code to assist the observer in selecting the appropriate code in case they have no wind gauge (Appendix D).

- Air temperature $\left({ }^{\circ} \mathrm{C}\right)$ and time (24-hour clock) will be recorded at the start and end of each $12.8 \mathrm{~km}$ transect.

- Percent cloud cover will be recorded to the closest $10 \%$.

- UTM co-ordinates will be taken at each 800m stop using GPS units (NAD 83).

- Observers will divide each survey site into four quadrants (NE, NW, SE, and SW) and record the number of Richardson's ground squirrels seen within $200 \mathrm{~m}$ and the habitat they were seen in for each quadrant. Habitat codes are provided at the bottom of the data sheet.

- Observers will record any disturbances within $200 \mathrm{~m}$ for each quadrant. Disturbance codes are provided at the bottom of the data sheet.

- Two counts will be conducted, one without and one with call playback (First count \#, Call playback \#). Each count will take two minutes. This will allow evaluation of the effectiveness of the call playback survey.

- Observers will record and burrows seen at each stop.

- Observers will record any additional species seen (Appendix B).

\subsection{Data Analysis}

Data collected from ground squirrel surveys will be used to develop yearly trend data for the entire grassland population, for each of the five areas (Hanna, Brooks, Lethbridge, Medicine Hat and the Foothills Fescue Region), and for the individual blocks. The two counts, one without and one with the use of call playback, are taken so that a paired t-test can be conducted to determine whether the number of ground squirrels seen differs statistically between the two methods. Route regression analysis will also be conducted to determine statistically yearly trends in the population. Richardson's ground squirrel trends will then be compared to ferruginous hawk trends to determine similarity in 
population fluctuations over time. This information may also be used to understand how fluctuations in ground squirrel populations may affect ferruginous hawk populations.

\subsection{Survey Protocol Evaluation}

An evaluation of the survey will occur after one year to determine whether visual counts without call playbacks are necessary. If deemed that surveys with call playback result in higher numbers of ground squirrels the surveys with no call playback will then be removed from the survey protocol. Upon the third year and subsequent years a statistical analysis will be performed and evaluated on the data. Changes in the statistical methods used may also occur depending on the results of the evaluation. A full review and evaluation of statistical methods and survey protocols will occur in 2008.

\subsection{EQUIPMENT NEEDED}

- Data Sheets: Appendix A

- List of Other Species: Appendix B

- Clipboard

- GPS unit (NAD 83)

- Pencil

- Thermometer

- Alarm Call Tape/CD

- Caller (Johnny Stewart, Dennis Kirk, Large Ghetto Blaster, etc)

- Binoculars

- Scope (recommended)

- Wind Gauge (recommended)

- Range Finder (recommended) 


\subsection{LITERATURE CITED}

Alberta Sustainable Resource Development. 2001. The general status of Alberta wild species 2000. Alberta Sustainable Resource Development, Fish and Wildlife Service, Edmonton, AB. 46 pp.

Hare, J.F. and B.A. Atkins. 2001. The squirrel that cried wolf: reliability detection by juvenile Richardson's ground squirrel (Spermophilus richardsonii). Behavioral Ecology and Sociobiology. 50: 108-112

Kirk, D.A. and U. Banasch. 1996. Second updated status report of the prairie falconFalco mexicanus in Canada. Committee on the Status of Endangered Wildlife in Canada. 8 pp.

Leung, M.C. 1991. Status, range, and habitat of Spermophilus saturatus in British Columbia. M. Sc. Thesis, University. B.C., Vancouver, BC.

Lishak, R.S. 1977. Censusing 13-lined ground squirrels with adult and young alarm calls. Journal of Wildlife Management. 41: 755-759

Lishak, R.S. 1982. Thirteen-lined ground squirrel. Pages 156-159 in David, E. Davis ed. CRC handbook of census methods for terrestrial vertebrates. CRC Press, Inc., Boca Raton, FL. 397 pp.

Menkens, G.E., Jr., D.E. Biggins, and S.H. Andersons. 1990. Visual counts as an index of white-tailed prairie dog density. Wildlife Society Bulletin 18: 290-296.

Michener, G.R. 1996. Establishment of a colony of Richardson's ground squirrels in southern Alberta. Pp. 303-308- in Proceedings of the fourth prairie conservation and endangered species workshop. Edited by W.D. Willms and J.F.Dormaar. Provincial Museum of Alberta. Natural History Occasional Paper 23:1-337

Michener, G.R. 1998. Sexual differences in reproductive effort of Richardson's ground squirrels. Journal of Mammalogy. 79: 1-19

Michener, G.R. 2002a. Richardson's ground squirrel (Spermophilus richardsonii). University of Lethbridge Online Paper (http://home.uleth.ca/ michener)

Michener, G.R. 2000b. Seasonal use of subterranean sleep and hibernation sites by adult female Richardson's ground squirrels. Journal of Mammology. 83: 999-1012

Michener, G.R. and J.K. Schmutz. 2002. Richardson's ground squirrel- Spermophilus richardsonii. Alberta Prairie Conservation Forum- Prairie Notes Online Paper (http://www.albertapcf.ab.ca/prairie_notes.htm) 
Ministry of Environment, Lands and Parks Resource Inventory Branch. 1998. Inventory methods for pikas and sciurids: pikas, marmots, woodchuck, chipmunks, and squirrels- standards for components of British Columbia biodiversity No.29. Prepared for Terrestrial Ecosystem Task Force Resources Inventory Committee. $70 \mathrm{pp}$.

NatureServe Explorer: An online encyclopaedia of life [web application]. 2001. Version 1.6. Arlington Virginia, USA: NatureServe. Available: http://www.natureserve.org/explorer. (Accessed: July 19, 2002).

Powell, K.L., R.J. Robel, K.E. Kemp, and M.D. Nellis. 1994. Above ground counts of black-tailed prairie dogs: temporal nature and relationship to burrow entrance density. Journal of Wildlife Management. 58: 361-366.

Reynolds, H.W., S.J. Barry, and H.P.L. Kiliaan. 1999. Small mammal component report: Canadian Forces Base Suffield National Wildlife Area. Canadian Wildlife Service, Edmonton, AB. 140 pp.

Russell, R.F. 2002. 2002 burrowing owl trend block survey and monitoring, Brooks area. Alberta Sustainable Resource Development, Fish and Wildlife Division. Alberta Species at Risk Report No. 58, Edmonton, AB 10 pp.

Scobie, D. 2002. 2001 burrowing owl trend block survey and monitoring, Brooks and Hanna areas. Alberta Sustainable Resource Development, Fish and Wildlife Division. Alberta Species at Risk Report No. 51, Edmonton, AB 13 pp.

Smith, H.C. 1993. Alberta mammals- An Atlas and Guide. The Provincial Museum of Alberta. Edmonton, AB. 238 pp

Schmutz, J.K., and Hungle, D.J. 1989. Populations of ferruginous and Swainson's hawks increase in synchrony with ground squirrels. Canadian Journal of Zoology. 67: $2596-2601$

Taylor, B.N. 2003. Stratification and standardisation: ferruginous hawk population estimates and a protocol for ferruginous hawk surveys in Alberta. Alberta Sustainable Resource Development, Fish and Wildlife Division, Alberta Species at Risk Report No.70, Edmonton, $\mathrm{AB} 17 \mathrm{pp}$.

Usher, R.G., J.A. Dechka, and G. L. Holroyd. 1993. Assessment of critical prairie falcon foraging habitat in southern Alberta using satellite imagery and GIS technology. Canadian Wildlife Service report. Edmonton, AB. 4 pp

Van Horne, B., R.L. Schooley, S.T. Knick, G.S. Olson, and K.P. Burnham. 1997. Use of burrow entrances to indicate densities of Townsend's ground squirrels. Journal of Wildlife Management. 61: 92-101 
APPENDIX A

(Richardson's ground squirrel survey map and data sheet)

FEHA Block \#:

Observer:

Date $(\mathrm{dd} / \mathrm{mm} / \mathrm{yy})$ :

Meridian: TWP: $\quad$ RGE: SE Section of Block:

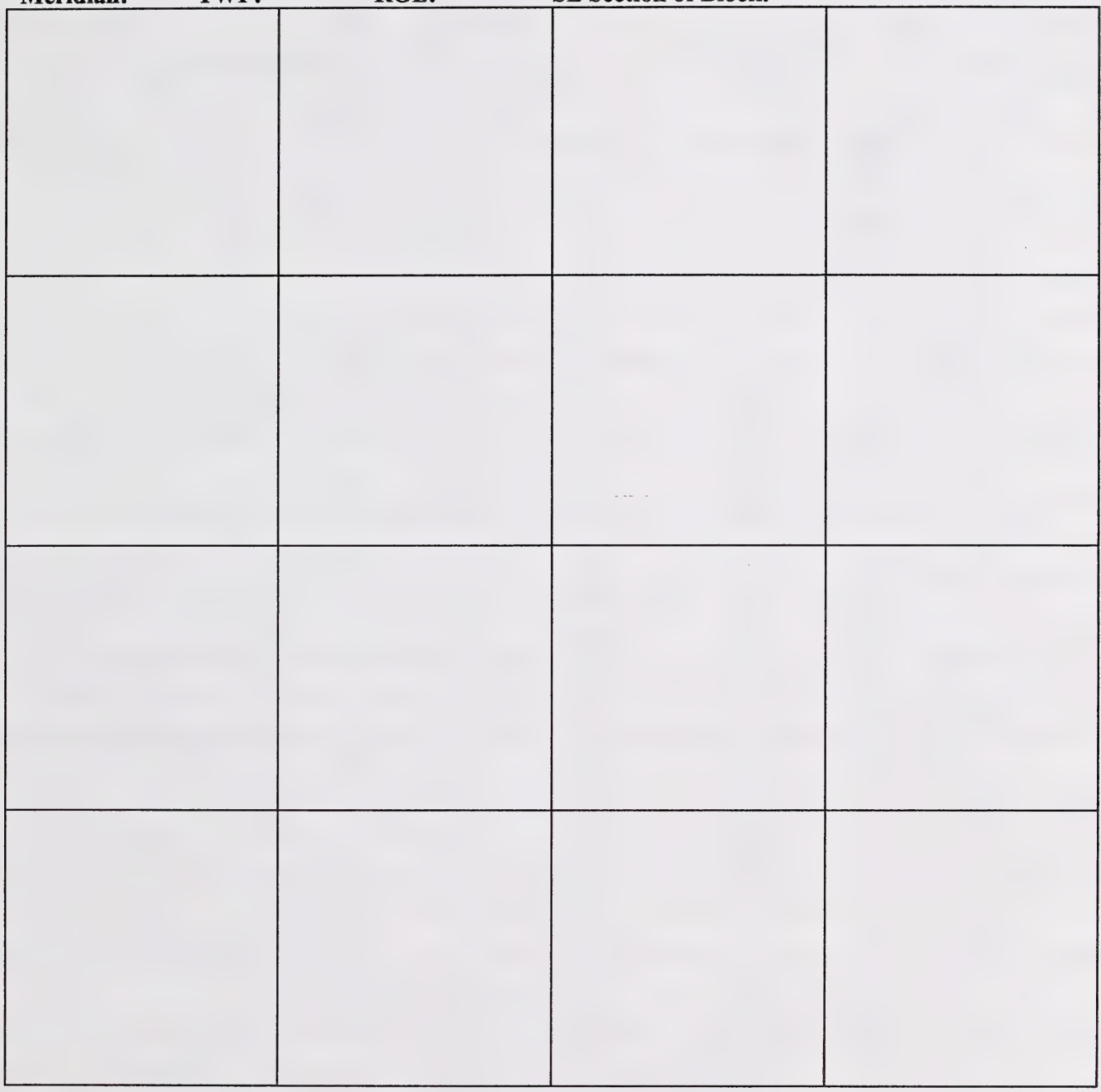

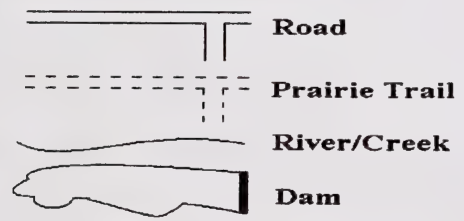

Crop, Irrigated, Hay, or Summerfallow
Native Pasture Tame Pasture

t or ts single or 1-10 trees

b or bs single or 1-10 bushes

DOR W

$\longrightarrow$

Dugout or Wetland

Cluster of trees/bushes

Shelterbelt

Species Observation

(1)

Abandoned farm/house with trees

Occupied farm/house with trees

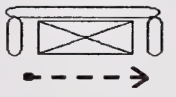

$\oplus$
RGSQ Transect

Point Sites 
FEHA Block \#:

Date $(\mathrm{dd} / \mathrm{mm} / \mathbf{y y})$

Weather: Sunny Partially Cloudy Rain Overcast

Wind (Beaufort Scale): $123456>6$

\% Cloud Cover: 1-10 $11-20 \quad 21-30 \quad 31-40 \quad 41-50 \quad 51-60 \quad 61-70 \quad 71-80 \quad 81-90 \quad$ 91-100

\begin{tabular}{|c|c|c|c|c|c|c|c|c|c|}
\hline \multicolumn{2}{|c|}{$\begin{array}{c}\text { GPS Location } \\
\text { (NAD 83) }\end{array}$} & \multirow{2}{*}{ Stop \# } & \multirow{2}{*}{\multicolumn{2}{|c|}{$\begin{array}{l}\text { Number Seen } \\
\text { (First Count, Call Playback } \\
\text { Count) }\end{array}$}} & \multirow{2}{*}{\multicolumn{2}{|c|}{$\begin{array}{c}\text { *Habitat } \\
\text { (Mark two habitat types if } \\
\text { ground squirrels location } \\
\text { differs from the main habitat } \\
\text { type) }\end{array}$}} & \multirow{3}{*}{$* *$ Disturbances } & \multirow{2}{*}{$\begin{array}{l}\text { Ground } \\
\text { squirrel } \\
\text { colony } \\
(\mathbf{Y} / \mathbf{N}) \\
\end{array}$} & \multirow{2}{*}{$\begin{array}{l}\text { Other } \\
\text { Species }\end{array}$} \\
\hline Northing & Easting & & & & & & & & \\
\hline & & \multirow[t]{2}{*}{1} & NW: , & NE: , & NW: & NE: & & & \\
\hline & & & SW: , & SE: & SW: & SE: & & & \\
\hline & & \multirow{2}{*}{2} & NW: , & NE: , & NW: & NE: & & & \\
\hline & & & SW: , & SE: , & SW: & SE: & & & \\
\hline & & \multirow{2}{*}{3} & NW: , & NE: & NW: & NE: & & & \\
\hline & & & SW: , & SE: & SW: & SE: & & & \\
\hline & & \multirow{2}{*}{4} & NW: , & NE: , & NW: & NE: & & & \\
\hline & & & SW: , & SE: , & SW: & SE: & & & \\
\hline & & \multirow{2}{*}{5} & NW: , & NE: , & NW: & NE: & & & \\
\hline & & & SW: , & SE: , & SW: & SE: & & & \\
\hline & & \multirow{2}{*}{6} & NW: , & NE: , & NW: & NE: & & & \\
\hline & & & SW: , & SE: , & SW: & SE: & & & \\
\hline & & \multirow{2}{*}{7} & NW: , & NE: , & NW: & NE: & & & \\
\hline & & & SW: , & SE: , & SW: & SE: & & & \\
\hline & & \multirow{2}{*}{8} & NW: , & NE: , & NW: & NE: & & & \\
\hline & & & SW: , & SE: , & SW: & SE: & & & \\
\hline & & \multirow{2}{*}{9} & NW: , & NE: , & NW: & NE: & & & \\
\hline & & & SW: , & SE: , & SW: & SE: & & & \\
\hline & & \multirow{2}{*}{10} & NW: , & NE: , & NW: & NE: & & & \\
\hline & & & SW: , & SE: , & SW: & SE: & & & \\
\hline & & \multirow{2}{*}{11} & NW: , & NE: , & NW: & NE: & & & \\
\hline & & & SW: , & SE: , & SW: & SE: & & & \\
\hline & & \multirow{2}{*}{12} & NW: , & NE: , & NW: & NE: & & & \\
\hline & & & SW: , & SE: , & SW: & SE: & & & \\
\hline & & \multirow{2}{*}{13} & NW: , & NE: , & NW: & NE: & & & \\
\hline & & & SW: , & SE: , & SW: & SE: & & & \\
\hline & & \multirow{2}{*}{14} & NW: , & NE: , & NW: & NE: & & & \\
\hline & & & SW: , & SE: , & SW: & SE: & & & \\
\hline & & \multirow{2}{*}{15} & NW: , & NE: , & NW: & NE: & & & \\
\hline & & & SW: , & SE: , & SW: & SE: & & & \\
\hline & & \multirow{2}{*}{16} & NW: , & NE: , & NW: & NE: & & & \\
\hline & & & SW: , & SE: , & SW: & SE: & & & \\
\hline & & \multirow{2}{*}{17} & NW: , & NE: , & NW: & NE: & & & \\
\hline & & & SW: , & SE: , & SW: & SE: & & & \\
\hline
\end{tabular}

${ }^{*} \mathbf{C}=$ Crop, $\mathbf{N p a}=$ Native Pasture, $\mathbf{T p a}=$ Tamed Pasture, $\mathbf{H}=$ Hayland, $\mathbf{F}=$ Farmyard, $\mathbf{A B F}=$ Abandoned Farmyard, $\mathbf{D}=$ Ditch, $\mathbf{I C}=$ Irrigated Crop, $\mathbf{I P}=$ Irrigated Pasture, $\mathbf{O}=$ Other

** $\mathbf{W}=$ Well Site, $\mathbf{R}=$ Road Adjacent, $\mathbf{F L}=$ Fence Line, $\mathbf{P L}=$ Power Line, $\mathbf{D U G}=$ Dugout, $\mathbf{P I P}=$ Pipe Line

DIS= Other disturbance 


\section{APPENDIX B}

Other species list (Alberta Sustainable Resource Development 2001)

\begin{tabular}{|l|c|}
\hline \multicolumn{1}{|c|}{ Common/Latin names } & Code to use on data sheet \\
\hline American Badger/ Taxidea taxus & BADG \\
\hline Baird's Sparrow/Ammodramus bairdii & BDSP \\
\hline Bald Eagle/Haliaeetus leucocephalus & BAEA \\
\hline Bobolink/Dolichonyx oryzivorus & BOBO \\
\hline Bullsnake/ Pituophis catenifer & BULL \\
\hline Burrowing Owl/ Athene cunicularia & BUOW \\
\hline Coyote/ Canis latrans & COYO \\
\hline Ferruginous Hawk/ Buteo regalis & FEHA \\
\hline Golden Eagle/Aquila chrysaetos & GOEA \\
\hline Great Blue Heron/ Ardea herodias & GBLH \\
\hline Lark Bunting/Calamospiza melanocorys & LKBU \\
\hline Loggerhead Shrike/ Lanius ludovicianus & LOSH \\
\hline Long-Billed Curlew/ Numenius americanus & LBCU \\
\hline Long-Tailed Weasel/ Mustela frenata & LTWE \\
\hline Mountain Plover/Charadrius montanus & MTPL \\
\hline Peregrine Falcon/ Falco peregrinus & PEFA \\
\hline Prairie Falcon/ Falco mexicanus & PRFA \\
\hline Prairie Rattlesnake/ Crotalus viridis & PRRA \\
\hline Pronghorn/Antilocapra americana & PRON \\
\hline Red Fox/ Vulpes vulpes & REFO \\
\hline Red-tailed Hawk/ Buteo jamaicensis & RTHA \\
\hline Sage Grouse/ Centrocercus urophasianus & SAGR \\
\hline Sage Thrasher/Oreoscoptes montanus & SATH \\
\hline Sandhill Crane/ Grus Canadensis & SACR \\
\hline Sharp-tailed Grouse/Tympanuchus phasianellus & STGR \\
\hline Short-eared Owl/Asio flammeus & SEOW \\
\hline Sprague's Pipit/Anthus spragueii & SPPI \\
\hline Swainson's Hawk/ Buteo swainsoni & SWHA \\
\hline Swift Fox/ Vulpes velox & SWFO \\
\hline Thirteen-lined Ground Squirrel/Spermophilus tridecemlineatus & TLGS \\
\hline Trumpeter Swan/Cygnus buccinator & TPSW \\
\hline Upland Sandpiper/ Bartramia longicauda & UPSA \\
\hline Whooping Crane/Grus americana & WOCR \\
\hline & \\
\hline & \\
\hline & \\
\hline
\end{tabular}




\section{APPENDIX C \\ Survey summary sheet}

- The survey period will occur during the first three weeks of April.

- Surveys will take place from 75 minutes after sunrise until 1200 hours and then from 1600 hours until 75 minutes prior to sunset. These are the most active times for ground squirrels.

- No surveys will take place during extreme temperatures $\left(>30^{\circ} \mathrm{C}\right)$ or days with adverse weather conditions (i.e. rain, snow, or strong winds ( $>4$ on the Beaufort scale) etc).

- Stops will be $800 \mathrm{~m}$ apart, except in cases were visibility is restricted due to topography. In these cases the observer will continue along the transect up to $400 \mathrm{~m}$ (the shorter the better) from the original site until $200 \mathrm{~m}$ in each quadrant can be surveyed. Regular stops every $800 \mathrm{~m}$ will then be continued from where the original stop was located.

- Observers will count the number of ground squirrels seen during a 2-minute period, 30 seconds in each quadrant (NE, NW, SE, and SW), within $200 \mathrm{~m}$ of their position with the aid of binoculars starting at one point and rotating around $360^{\circ}$.

- The number of Richardson's ground squirrels seen for each quadrant will be recorded on the data sheet.

- A call playback will then be used with the observers playing the call for 30 seconds towards each of the quadrants. Each quadrant will be recounted and the number of Richardson's ground squirrels seen will be recorded again on the data sheet adjacent to the first count (first count \#, call playback count \#) during the 30 second call playback.

- Habitat information and any disturbances will be recorded for each quadrant.

- GPS, northing and easting (NAD 83) locations will be taken at each stop.

- Any additional wildlife listed in Appendix B will be recorded at each site. Any additional species seen which do not occur on the list but which the observers deem important will be recorded.

- The observer will identify whether there is a colony (group of mounds) within each quadrant at each stop by marking yes (presence) or no (absence) in the column provided. 


\section{APPENDIX D}

Beaufort Scale

\begin{tabular}{|l|l|l|l|}
\hline Code & \multicolumn{2}{|l|}{ Wind Speed } & Beaufort wind description \\
\hline & kph & mph & \\
\hline 0 & $0-2$ & $0-1$ & Calm, smoke rises vertically \\
\hline 1 & $3-5$ & $2-3$ & Light air, smoke drifts \\
\hline 2 & $6-11$ & $4-7$ & Slight breeze, wind felt on face; leaves rustle \\
\hline 3 & $12-19$ & $8-12$ & Gentle breeze, leaves and small twigs in constant motion \\
\hline 4 & $20-30$ & $13-18$ & Moderate breeze, small branches sway; dust and loose paper rise \\
\hline 5 & $31-39$ & $19-24$ & Fresh breeze, small trees in leaf sway; thin branches sway \\
\hline 6 & $40-50$ & $25-31$ & Strong breeze, large branches in motion \\
\hline
\end{tabular}

(Scale continues to 12 , however for simplicity only the first 6 are shown) 


\section{List of Titles in This Series}

(as of March 2003)

No. 1 Alberta species at risk program and projects 2000-2001, by Alberta Sustainable Resource Development, Fish and Wildlife Division. (2001)

No. 2 Survey of the peregrine falcon (Falco peregrinus anatum) in Alberta, by R. Corrigan. (2001)

No. 3 Distribution and relative abundance of the shortjaw cisco (Coregonus zenithicus) in Alberta, by M. Steinhilber and L. Rhude. (2001)

No. 4 Survey of the bats of central and northwestern Alberta, by M.J. Vonhof and D. Hobson. (2001)

No. 52000 survey of the Trumpeter Swan (Cygnus buccinator) in Alberta, by M.L. James and A. James. (2001)

No. 6 2000/2001 Brassy Minnow inventory at Musreau Lake and outlet, by T. Ripley. (2001)

No. 7 Colonial nesting waterbird survey in the Northwest Boreal Region - 2000, by M. Hanneman and M. Heckbert. (2001)

No. 8 Burrowing owl trend block survey and monitoring - Brooks and Hanna areas, by D. Scobie and R. Russell. (2000)

No. 9 Survey of the Lake Sturgeon (Acipenser fulvescens) fishery on the South Saskatchewan River, Alberta (June-September, 2000), by L.A. Winkel. (2000)

No. 10 An evaluation of grizzly bear-human conflict in the Northwest Boreal Region of Alberta (19912000) and potential mitigation, by T. Augustyn. (2001)

No. 11 Harlequin duck monitoring in the Northern East Slopes of Alberta: 1998-2000 preliminary results, by J. Kneteman and A. Hubbs. (2000)

No. 12 Distribution of selected small mammals in Alberta, by L. Engley and M. Norton. (2001)

No. 13 Northern leopard frog reintroduction. Raven River - Year 2 (2000), by K. Kendell. (2001)

No. 14 Cumulative effects of watershed disturbances on fish communities in the Kakwa and Simonette watersheds. The Northern Watershed Project. Study 3 Progress report, by T. Thera and A. Wildeman. (2001)

No. 15 Harlequin duck research in Kananaskis Country in 2000, by C.M. Smith. (2001)

No. 16 Proposed monitoring plan for harlequin ducks in the Bow Region of Alberta, by C.M. Smith. (2001)

No. 17 Distribution and relative abundance of small mammals of the western plains of Alberta as determined from great horned owl pellets, by D. Schowalter. (2001)

No. 18 Western blue flag (Iris missouriensis) in Alberta: a census of naturally occurring populations for 2000, by R. Ernst. (2000)

No. 19 Assessing chick survival of sage grouse in Canada, by C.L. Aldridge. (2000) 
No. 20 Harlequin duck surveys of the Oldman River Basin in 2000, by D. Paton. (2000)

No. 21 Proposed protocols for inventories of rare plants of the Grassland Natural Region, by C. Wallis. (2001)

No. 22 Utilization of airphoto interpretation to locate prairie rattlesnake (Crotalus viridis viridis) hibernacula in the South Saskatchewan River valley, by J. Nicholson and S. Rose. (2001)

No. 23 2000/2001 Progress report on caribou research in west central Alberta, by T. Szkorupa. (2001)

No. 24 Census of swift fox (Vulpes velox) in Canada and Northern Montana: 2000-2001, by A. Moehrenschlager and C. Moehrenschlager. (2001)

No. 25 Population estimate and habitat associations of the long-billed curlew in Alberta, by E.J. Saunders. (2001)

No. 26 Aerial reconnaissance for piping plover habitat in east-central Alberta, May 2001, by D.R.C. Prescott. (2001)

No. 27 The 2001 international piping plover census in Alberta, by D.R.C. Prescott. (2001)

No. 28 Prairie rattlesnake (Crotalus viridis viridis) monitoring in Alberta - preliminary investigations (2000), by S.L. Rose. (2001)

No. 29 A survey of short-horned lizard (Phrynosoma hernandesi hernandesi) populations in Alberta, by J. James. (2001)

No. 30 Red-sided garter snake (Thamnophis sirtalis parietalis) education and relocation project - final report, by L. Takats. (2002)

No. 31 Alberta furbearer harvest data analysis, by K.G. Poole and G. Mowat. (2001)

No. 32 Measuring wolverine distribution and abundance in Alberta, by G. Mowat. (2001)

No. 33 Woodland caribou (Rangifer tarandus caribou) habitat classification in northeastern Alberta using remote sensing, by G.A. Sanchez-Azofeifa and R. Bechtel. (2001)

No. 34 Peregrine falcon surveys and monitoring in the Parkland Region of Alberta, 2001, by R. Corrigan. (2002)

No. 35 Protocol for monitoring long-toed salamander (Ambystoma macrodactylum) populations in Alberta, by T. Pretzlaw, M. Huynh, L. Takats and L. Wilkinson. (2002)

No. 36 Long-toed salamander (Ambystoma macrodactylum) monitoring study in Alberta: summary report 1998-2001, by M. Huynh, L. Takats and L. Wilkinson. (2002)

No. 37 Mountain plover habitat and population surveys in Alberta, 2001, by C. Wershler and C. Wallis. (2002)

No. 38 A census and recommendations for management for western blue flag (Iris missouriensis) in Alberta, by R. Ernst. (2002)

No. 39 Columbian mountain amphibian surveys, 2001, by D. Paton. (2002)

No. 40 Management and recovery strategies for the Lethbridge population of the prairie rattlesnake, by $\mathrm{R}$. Ernst. (2002) 
No. 41 Western (Aechmophorus occidentalis) and eared (Podiceps nigricollis) grebes of central Alberta: inventory, survey techniques and management concerns, by S. Hanus, $\mathrm{H}$. Wollis and L. Wilkinson. (2002)

No. 42 Northern leopard frog reintroduction - year 3 (2001), by K. Kendell. (2002)

No. 43 Survey protocol for the northern leopard frog, by K. Kendell. (2002)

No. 44 Alberta inventory for the northern leopard frog (2000-2001), by K. Kendell. (2002)

No. 45 Fish species at risk in the Milk and St. Mary drainages, by RL\&L Environmental Services Ltd. (2002)

No. 46 Survey of the loggerhead shrike in the southern aspen parkland region, 2000-2001, by H. Kiliaan and D.R.C. Prescott. (2002)

No. 47 Survey of native grassland butterflies in the Peace parkland region of northwestern Alberta - 2001, by M. Hervieux. (2002)

No. 48 Caribou range recovery in Alberta: 2001/02 pilot year, by T. Szkorupa. (2002)

No. 49 Peace parkland native grassland stewardship program 2001/02, by A. Baker. (2002)

No. 50 Carnivores and corridors in the Crowsnest Pass, by C. Chetkiewicz. (2002)

No. 512001 Burrowing owl trend block survey and monitoring, Brooks and Hanna areas, by D. Scobie. (2002)

No. 52 An evaluation of the ferruginous hawk population in Alberta based on recent trend data, by D.P. Stepnisky, G.L. Erickson, J. Iwaasa and B. Taylor. (2002)

No. 53 Alberta amphibian call surveys. A pilot year. Final report, by L. Takats and C. Priestley. (2002)

No. 54 Utilization of a roadside survey technique to survey burrowing owl (Athene cunicularia hypugaea) in southeastern Alberta, by J. Nicholson and C. Skiftun. (2002)

No. 55 Alberta species at risk program and projects 2001-2002, by Alberta Sustainable Resource Development, Fish and Wildlife Division. (2002)

No. 56 Developing a habitat-based population viability model for greater sage-grouse in southeastern Alberta, by C.L. Aldridge. (2001)

No. 57 Peregrine falcon surveys and monitoring in the Northeast Boreal Region of Alberta, 2001, by R. Corrigan. (2002)

No. 582002 burrowing owl trend block survey and monitoring, Brooks area, by R.F. Russell. (2002)

No. 59 Rare plant inventory of the eastern edge of the lower foothills natural subregion, west-central Alberta, by J. Doubt. (2002)

No. 60 Western (Aechmophorus occidentalis) and eared (Podiceps nigricollis) grebes of central Alberta: 2002 field summary, by S. Hanus, L. Wilkinson and H. Wollis. (2002)

No. 61 Inventory of western spiderwort (Tradescantia occidentalis) in Alberta: 2002, by S. Peters. (2003) 
No. 62 Bullsnakes (Pituophis catenifer sayi) in Alberta: literature review and data compilation, by K.J. Kissner and J. Nicholson. (2003)

No. 63 Distribution of Ord's kangaroo rats in southeastern Alberta, by D.L. Gummer and S.E. Robertson. (2003)

No. 64 Lethbridge prairie rattlesnake conservation project: 2002/2003 progress report, by R.D. Ernst. (2003)

No. 65 Short-horned lizard (Phrynosoma hernandesi hernandesi) populations in Alberta - 2002 survey results, by J.D. James. (2003)

No. 66 Inventory and monitoring protocol for naturally occurring western blue flag (Iris missouriensis) in Alberta, by R.D. Ernst. (2003)

No. 67 The use of call playbacks for censusing loggerhead shrikes in southern Alberta, by D.R.C. Prescott. (2003)

No. 68 Survey of bats in northeastern Alberta, by A. Hubbs and T. Schowalter. (2003)

No. 69 Survey protocol for the Richardson's ground squirrel, by B.A. Downey. (2003)

No. 70 Population estimates and a survey protocol for ferruginous hawks in Alberta, by B.N. Taylor. (2003)

No. 71 Testing methods for detecting wolverine, by G. Mowat, C. Kyle and D. Paetkau. (2003) 


